\title{
Factors Affecting Motivation in the Public Sector under the Context of Self-Determination Theory and Public Service Motivation: The Case of the Hellenic Agricultural Insurance Organization (H.A.I.O.)
}

Submitted 14/08/19, $1^{\text {st }}$ revision 09/09/19, $2^{\text {nd }}$ revision 11/10/19, accepted 07/11/2019

\begin{abstract}
:
Purpose: The main aim of this study is to develop and test a conceptual framework that explores the factors that motivate employees in public services. The study is based on two theories, the Self Determination Theory (SDT), and the Public Service Motivation (PSM).

Design/methodology/approach: The empirical testing of the proposed conceptual framework was conducted using a structured questionnaire that was distributed to 390 employees of a Greek public sector organization, namely the Hellenic Agricultural Insurance Organization (H.A.I.O.). The population of the study consists of 489 public servants. Exploratory factor analysis, confirmatory factor analysis and the structural equation modeling (SEM) technique were used to test the research hypotheses.

Findings: Results highlight, among others, the importance of work autonomy and job satisfaction and their impact on employees' intrinsic motivation. Moreover, empirical results emphasize the need for building a supportive work environment that contributes on employee satisfaction, autonomy and relatedness. Results also confirm the existence of a positive relationship among intrinsic motivation, public service motivation and job performance.

Practical implications: The findings suggest that in cases where external incentives are significantly limited (e.g., in the public sector), it is crucial to consider the importance of promoting and supporting intrinsic motivation and support public service incentives.

Originality/value: Self-determination theory seems to be poorly explored in the Greek public sector, and moreover, in economies and countries with similar characteristics. Therefore, it seems crucial to increase the knowledge about the real value of self-determination theory as a work motivation approach, especially in the public sector. Finally, research results may help supervisors and business leaders to implement appropriate systems and practices that promote a supportive environment in the workplace.
\end{abstract}

Martha I. Papadopoulou ${ }^{1 *}$, Efstathios D. Dimitriadis $^{2}$

Keywords: Self determination theory, public service motivation, intrinsic motivation.

JEL Codes: C12, J24, J28. Article Type: Research study.

\footnotetext{
1*Agronomist, Department of Management Science and Technology, School of Economics and Management, International Hellenic University, Kavala University Campus, marthapapad@yahoo.gr. An earlier version of this study has been presented in ICABE 2019 www.icabe.gr evaluated as one of the best in its category.

${ }^{2}$ Professor, Department of Management Science and Technology, School of Economics and Management, International Hellenic University, Kavala University Campus, edemit@mst.ihu.gr
} 


\section{Introduction}

In the context of a country in recession, efforts are underway to reform public administration, with the aim of ensuring a well-managed workforce capable of delivering public services cost-effectively, efficiently and effectively. Several initiatives have been taken to reform the public sector, to minimize the negative impact on employees' motivation in the new conditions that have been created. In addition, another development related to the financial and economic crisis is the public loss of public confidence in the various public service governance institutions, long-standing cultural issues that affect the prestige and social status of civil servants. The effort to ensure cost savings in public services has led to the introduction of what are often referred to as 'private sector practices'. In cases where external incentives, including remuneration, job security, etc., are significantly constrained, or even reduced, as is the case currently in the Greek public sector, it is extremely important to identify ways in which they can strengthen the intrinsic motivation of civil servants and find appropriate approaches that help public services to develop 'a culture based' on the promotion of intrinsic motivations of civil servants. The lack of such empirical studies in the Greek public sector as emerged from the literature review assisted to decision and choice of this research.

This study contributes to research in four different ways. Firstly, it supports the growing body of international literature and empirical studies that contain claims on the impact of intrinsic motivation and public service motivation, not only on performance but also on job satisfaction. Secondly, it makes a substantial contribution to the current situation in Greece by providing relevant empirical data, as research in this field is at a relatively early stage in the country. Thirdly, it provides a research framework for employee motivation which created using a methodological approach that combines two theories that are related to intrinsic motivation. Finally, from a practical point of view, results can in turn help supervisors and leadership to implement and support appropriate systems and practices that promote the emergence of a supportive workplace environment by enhancing efficiency and productivity. The rest of the paper is structured as follows: The second section presents the theoretical background while in the third section the proposed conceptual framework along with the research hyporheses are developed. The fourth section deals with methodological issues. The fifth section presents the empirical findings from the analysis of the research data and the research hypotheses are tested. The last section concludes the study.

\section{Theoretical background}

\subsection{Motivation}

The concept of employee motivation has been one of the most important research subjects in both the science of psychology and that of human resource management, as it is directly related to human behaviour and organizational performance. Kelly 
(1974) believes that motivation is related to those forces that change the direction, quality and intensity of behaviour. Barron (1983) defines motivation by stating that 'motivation is a set of processes that relate to a type of force that activates behaviour and directs it to achieve specific goals'. Brewer and Selden (1998) describe motivation in the public sector as the driving force that drives individuals to perform their public tasks properly. According to Erven and Milligan (2001) motivation is an internal force that drives employee behaviour. Berman et al. (2010) argue that employee motivation is the key to increase productivity and efficiency, so it is easy to understand the important role of 'excellence at work'. Motivation is a set of processes that 'accounts for an individual's intensity, direction, and persistence of effort towards attaining a goal' (Robbins and Judge, 2011, p. 202).

\subsection{Self Determination Theory (SDT)}

SDT founded by Eduard L. Deci and Richard M. Ryan, is one of the leading motivational theories in the field of social psychology that has been successfully applied in all fields including education, sports, health as well as motivation and job management (Deci and Ryan, 1985; Ryan and Deci, 2017). It is a theory of approach to human motivation and personality and emphasizes the importance of both internal sources of personality development and regulation of individual behaviour (Ryan et al., 1997; Ryan and Deci, 2000). SDT is used to understand work motivation (Gagné and Deci, 2005; Deci et al., 2017). According to this theory human behaviour is triggered by three types of motivation (a) intrinsic motivation, (b) extrinsic motivation and (c) lack of motivation (Amotivation) (Deci and Ryan, 1985; Deci et al., 2017).

Deci and Ryan (1985) state that there are three basic and universal psychological needs, namely: (a) autonomy, (b) relatedness and (c) competence, which must be satisfied to promote intrinsic motivation. According to Rigby and Ryan (2018, pp. 138-139) 'Autonomy is the basic need to be the author of one's life-to have a sense of choice and self-endorsement of one's actions, Relatedness is our basic need to feel we belong and "matter" to others, while Competence is our basic need to feel effective, to be successful, and to grow'. Especially when these three needs are supported and fulfilled in a social context, people experience more vitality, selfmotivation and well-being. Discouraging or frustrating these basic needs leads to diminished self-motivation and greater loss (Ryan and Deci, 2017).

\subsection{Public Service Motivation (PSM)}

According to Perry and Hondeghem (2008) the public sector has traditionally provided some powerful extrinsic incentives that could attract people, such as tenure security, career prospects, growth opportunities and the pension system. Vandenabeele (2008) also identifies 'quality of life' as an attraction to work in the public sector, while people are under the impression that the public sector offers better flexibility to those who combine work with family or other commitments. 
PSM concerns public-based incentives and actions designed to benefit others, society at large, and to shape people's well-being (Perry and Hondeghem, 2008; Perry et al., 2010).

Although the term 'PSM' was first used by Rainey in 1982 to express the specific incentives associated with public service, Perry and Wise (1990) were the ones who offered the first conceptual definition where public service motivation "represents an individual's predisposition to respond to motives grounded primarily or uniquely in public institutions" (Perry and Wise, 1990). Moreover, they consider that PSM encompasses thinking around related concepts such as altruism and prosocial behavior. Perry (1996) and Kim et al. (2012) state that PSM is consisted of four dimensions: 1. Attraction to public service (APS), 2. Commitment to public values (CPV), 3. Compassion (COM), 4. Self-sacrifice (SS).

PSM is a significant topic since it considers that the public service can attract, retain and motivate people who are able of delivering on the objectives of the public service. Scholars hypothesize that public service motivation is a form of work motivation that leads to increased commitment, obligation, and performance (Brewer and Selden 1998; Moynihan and Pandey 2007; Ritz 2009; Bellé and Cantarelli 2012; Ritz et al., 2016).

\subsection{Previous Studies}

Intrinsic motivation as a predictor of performance is strongly supported by research in sports and educational settings (Kuvaas, 2008). In addition, Deci et al. (2017) cite several studies that have found a positive relationship between intrinsic or autonomous motivation and work/job performance in work environments. However, despite the importance of incentives among public sector employees in a time of transformation towards a more business-oriented approach, empirical research on public sector employee motivation is not extensive in Greece. Manolopoulos (2008) investigated the relationships between the motivating factors of employees and their performance in the public sector in Greece. The results have shown that external incentives, such as payment and job security, are powerful drivers and that internal incentives such as creative work, recognition and autonomy in the workplace appear to contribute to increased employee performance. Another study by Kalliga (2011) aimed at investigating motivational factors in the public sector in Greece. Results proved that the majority of respondents $(83,3 \%)$ consider, as far as exploring the question of linking workers' motivation with financial incentives, that these are not the only incentives. They consider hierarchically that interpersonal relationships that are developed in the workplace, the development of new skills and new knowledge, and the development of independent thinking, play a key role in motivation.

Kuvaas (2008) aimed to test the relationship between intrinsic motivation and job performance among individuals across a wide range of public service employees in Norway. Results showed that the relationship between autonomy at work and job 
performance as well as the relationship between work interdependence and job performance are partly mediated by intrinsic motivation, whereas the relationship between management support for development, competence and autonomy, with work performance are fully mediated by intrinsic motivation. The aim of the study by Fernet et al. (2015) in Canada was to study and deepening of the understanding of the motivational mechanisms involved in the relationship between transformational leadership and employee functioning. They concluded that through their actions, transformational leaders can influence perceptions of work resources and create an environment conducive to communication and exchange, autonomy, and individual recognition. Several studies have been published debating on the role of SDT in job satisfaction and job performance (see among others: Bono and Judge, 2003; Piccolo and Colquitt, 2006; Moran et al., 2012; Park and Rainey, 2012; Van den Broeck et al., 2013; Wilkesmann and Schmid, 2014; Graves et al., 2015; Howard et al., 2016).

Research on public service motivation has grown significantly over the last 25 years and while it has been primarily focused in the United States and firmly in the public administration sector, it has become increasingly international and multidisciplinary in recent years, but not fully integrated with human resource management practices in public organizations. In a review article, Vandenabeele et al. (2014) examined the evolution of the perception of public service motivation and noted that the majority of articles indicate that the influence of the concept of public service motivation has significantly accelerated. Several studies have documented a positive relationship between public service motivation and job performance, and public service motivation and job satisfaction, at both the individual and organizational level. Starting from the US, Naff and Grum (1999) found significant positive correlations between the level of public service motivation, federal employees' job satisfaction, their performance, and their willingness to remain in public employment. Brewer and Selden (2000) have shown that public service motivation plays an important role in determining the effectiveness of their service and can therefore influence the organizational performance of public organizations in the US. Results of Kim (2005) in Korea are consistent to those of Brewer and Selden (2000). Moreover, Kim (2012) not only found the direct relationship between PSM and job satisfaction but also mediated this relationship by confirming the person-organization theory (P-O fit).

A broad body of studies have been conducted for the US environment with mixed results (Alonso and Lewis, 2001; Bright, 2007; Wright and Pandey, 2008). Several studies are coming from Europe conveying interesting results advocating that PSM influences the outcome of ordinary and daily public service provision (Ritz, 2009; Vandenabeele, 2009; Leisink and Steijn, 2009; Andersen and Serritzlew, 2012; Belle, 2013; Vandenabeele, 2014; Andersen et al., 2014). Taylor's (2008) results from Australia showed a direct and significant relationship between public service motivation and job satisfaction and organizational commitment. In addition, the results showed that external organizational rewards and relationships with management and colleagues were not found to be significantly related to PSM 
confirming the studies of Naff and Grum (1999) and Camilleri (2007). Moreover, Liu et al. (2008) showed that PSM in the West also exist in China.

Finally, Vandenabeele (2014) found that there is a positive relationship between PSM and leadership promotion of public values, moderated by the basic psychological needs satisfaction, while Bright (2007) revealed that SDT motivation is strongly related to job satisfaction than PSM.

\section{The Proposed Conceptual Framework (Research Hypotheses)}

\subsection{Intrinsic Motivation and Job Performance}

SDT suggests that the social environment influences intrinsic motivation through its effects on satisfying the needs of individuals' autonomy, relatedness and competence (Deci and Ryan, 1985). Motivation is an important factor for the proper functioning of employees and the productivity of Organizations (Pinder, 2008). In this respect, intrinsic motivation concentrates on the highest levels of effort (Meyer et al., 2004), as it is associated with high levels of energy (Ryan and Deci, 2008) and persistence (Vallerand and Bissonnette, 1992). In addition, the intrinsic motivation according to Van den Broeck et al. (2013) is positively associated with excitement and commitment, as well as well-being (Nix et al., 1999).

All of these positive effects indicate that employees can energize and focus their interest in performing their work in a more integrated and efficient way (Kuvaas et al., 2017), while Gagné and Deci (2005) cite evidence of a positive relationship between intrinsic motivation and job performance. Thus, it is hypothesized:

\section{H1: Intrinsic motivation is positively related with job performance.}

\subsection{Satisfaction of the Basic Psychological Needs}

According to Eisenberger et al. (2002) and Gagné and Deci (2005) supervisory authorities are at the centre of motivation. They influence work assignments, rewards and penalties for employees and provide the necessary and critical resources to perform a job. SDT researchers who have examined the role of autonomy in work and the support of supervisors being the most well-studied factor of intrinsic motivation (Black and Deci, 2000; Pelletier et al., 2001; Muraven et al., 2008; Gillet et al., 2013) found that employees' perceptions of autonomy support were positively associated with autonomous work motivation. Deci et al. (1989) as well as Hardré and Reeve (2009) consider that in order supervisory authorities to function supportively and to enhance employee autonomy, should emphasize the choice rather than controlling their duties and recognize their feelings and perspectives.

Kelly (1992) and Hardré and Reeve (2009) proved that performance enhancement is more likely to occur when autonomous work planning improves intrinsic motivation. 
Previous research has indicated that support for autonomy leads to intrinsic and autonomous motivation, which in turn is associated with positive outcomes in the workplace (Gagné et al., 1997; Gagné et al., 2000; Deci et al., 2001; Slemp et al., 2018). Graves et al. (2015) claim that employees must experience high levels of safety, self-esteem and the ability to deal with 'stressful' situations from their managers, which enhances their ability to act on their values, goals and interests in order to increase the likelihood of acting with a more self-determined profile dominated by internal rather than external motivation.

Overall, research has supported that autonomy, supportive work environments, and supervisory management methods promote basic needs for satisfaction of autonomy, competence and relatedness (Bono and Judge, 2003; Piccolo and Colquitt, 2006; Kuvaas, 2008). Therefore, intrinsic motivations in turn lead to persistence, effective performance, job satisfaction, positive work attitudes in general, organizational commitment and psychological well-being (Gagné and Deci, 2005). Based on the above the second and third hypotheses are formed as below:

H2: The relationship between supervisor support (development for autonomy and competence) and job performance is mediated by intrinsic motivation.

H3: The relationship between job autonomy and job performance is mediated by intrinsic motivation.

SDT states that intrinsic motivation can be developed in environments characterized by feelings of security and relatedness (Ryan and Deci, 2000). Tasks characterized by high levels of duties' interdependence and mutual dependence, require spontaneous offering and receiving, collaboration and compromise among employees, and therefore, interdependence of tasks can contribute to meeting the needs of relatedness (Organ, 1988; Podsakoff et al., 2000). The interdependence of work reflects the degree to which a job depends on others and others on it, in order to this to be performed (Morgeson and Humphrey, 2006). Bachrach et al. (2006) suggest that interdependence of work can satisfy the needs of relatedness, and thus, reinforce intrinsic motivation, as it promotes communication, assistance and information exchange, organizational behaviour, expectations for help and rules of cooperation. Moreover, Kuvaas (2008) found that the relationship between task independence and job performance are partly mediated by intrinsic motivation. The following hypothesis may therefore be formulated as:

H4: The relationship between task interdependence and job performance is mediated by intrinsic motivation.

\subsection{Job Satisfaction and Job Performance}

In a meta-analysis Judge et al. (2001) confirmed the moderately positive relationship between job performance and job satisfaction. They noted, however, that significant variability in the magnitude of this relationship was found in all studies, and that this 
variability appeared to be due to the way that concepts of performance and satisfaction were assessed with respect to other factors such as job complexity. Intrinsic motivation has been found to be superior for promoting job performance at workplaces, that include both complex and personally important tasks, tasks that require disciplined commitment and has been linked to job satisfaction (Baard et al., 2004). In contrast, external or controlled incentives have been found to provide comparable or superior short-term performance in boring tasks (Grolnick and Rayan, 1987), although they have been associated with less satisfaction and adaptation to these workplaces (Ilardi et al., 1993).

According to Gagné and Deci (2005) intrinsic-autonomous versus extrinsiccontrolled incentives as well as the content of the work that drives these incentives can mitigate the relationship between job satisfaction and job performance. They found that autonomous versus controlled motivation at work incorporates many important elements of job content, work context, factors that generally determine the environment of the work, as well as individual differences in the general causality guidelines, which are factors that can coordinate this relationship between performance and job satisfaction. As a result, employees perform effectively in these jobs, leading to the satisfaction of their basic psychological needs (for autonomy, competence and relatedness) resulting in satisfaction and generally positive attitudes towards their work.

In summary, the various aspects of the work, including complexity, challenge, importance, choice and participation, as well as the enhancement of autonomy and a supportive climate, can lead employees to give autonomous and intrinsic motivation to their work, which in turn results in work being performed efficiently and employees receiving high levels of job satisfaction (Gagné and Deci, 2005). Therefore, the hypothesis formulated as follow:

\section{H5: The relationship between job satisfaction and job performance is mediated by intrinsic motivation.}

\subsection{Public Service Motivation and Job Performance}

Job performance is perhaps the most central concept in public administration research (Andersen et al., 2016). There are many incentives that drive people to perform public services, but it is important to identify what incentives need to be addressed to make people more effective (Brewer et al., 2000; Brewer 2008; Ritz et al., 2016). According to Perry and Wise (1990), highly motivated public service employees seek employment in public services because they provide them with sufficient opportunities to engage with the public service and are highly performing in their service because they believe their work makes sense. Wright and Pandey (2008) further argue that public sector employees who have high public service incentives are expected to work harder, perform better in their duties precisely 
because the Organizations they work for, have the opportunity to offer services that they consider important and inherently satisfactory.

According to Brewer (2008) and Dilulio (1994) a high commitment to public service can lead employees to work beyond their own interests and to do more than they are asked to do. In general, many studies (see: Naff and Grum, 1999; Brewer and Selden, 2000; Kim, 2005; Bright, 2007; Leisink and Steijn, 2009; Ritz, 2009; Vandenabeele, 2009; Andersen and Serritzlew, 2012; Bellé, 2013; Gould-Williams et al., 2015) claim that Organizations that are able to attract, socialize, and retain employees with higher levels of motivation for public service are expected to have higher levels of performance, precisely because their employees perform better, work harder and help each other. Thus, the sixth hypothesis is stated as follow:

H6: Public service motivation is positively related with job performance.

\subsection{Public Service Motivation and Job Satisfaction}

A significant number of empirical research supports the view that the motivation for public service is closely linked to job satisfaction (Weiss 2002; Bright 2008; Steijn 2008; Wright and Pandey 2008). Job satisfaction can be seen as a consequence of the public service motivation in the public sector, as the situation of public sector job appears to be capable of meeting the needs of individuals willing to help others (Perry and Wise 1990; Pandey and Stazyk, 2008). The direct relationship between PSM and job satisfaction has been supported by, among others, in Australia by Taylor (2008), in Belgium by Vandenabeele (2009), in China by Liu et al. (2008), in Korea by Kim (2011) and in United States by Naff and Crum (1999). Perry and Wise (1990), Taylor (2008), as well as Kim (2012) and Breaugh et al. (2017) argue that people with high public service motivation are more satisfied with their work in the public sector and more committed to the organizations they serve, precisely because they work in roles that satisfy their social orientation. Thus, the seventh hypothesis is formed as follow:

\section{H7: Public service motivation is positively related with job satisfaction.}

\subsection{Self Determination Theory and Public Service Motivation}

Both SDT and PSM have been used alternatively in public sector incentive research, where on a fundamental level, the first concerns a universal motivation theory that is applied in many contexts (Ryan and Deci, 2002), PSM relates to a theory of motivation that explains the incentives associated with service delivery in society (Perry et al., 2010). Those theories differ because PSM does not require the presence of pleasant emotions that are characteristic of intrinsic motivation (Perry et al., 2010). Breaugh et al. (2017) have shown that SDT is more related to job satisfaction and that employees with high levels of PSM have more stable job satisfaction than their lower-level counterparts. Andrews (2016) demonstrates that PSM and SDT are 
complementary theoretical approaches and that this complementarity can provide clearer guidance to supervisors and broaden their understanding of incentives in public services.

Perry and Vandenabeele (2015) recognize the SDT as a necessary basis for understanding the dynamics associated with motivation in public services. Vandenabeele (2007) argues that in order to allow PSM to emerge, public Organizations must meet the three psychological needs, allowing a more autonomous motivation and moreover, he claims that the PSM concerns a dynamic trait mediated by the degree to which the three basic psychological needs of the theory of SDT are met. Grant (2008), Vandenabeele (2014), Schott and Pronk (2014) and Andrews et al. (2015) are in line to the previous studies. Thus, the last hypothesis could be formed as follow:

H8: Public service motivation is positively related with intrinsic motivation and particularly with satisfaction of the three basic psychological needs for autonomy, competence and relatedness.

The synthesis of the research hypotheses presented above leads to the formation of the proposed conceptual framework of the present study (Figure 1), which focuses on the relationships among the research factors examined.

Figure 1. The proposed conceptual framework of the study

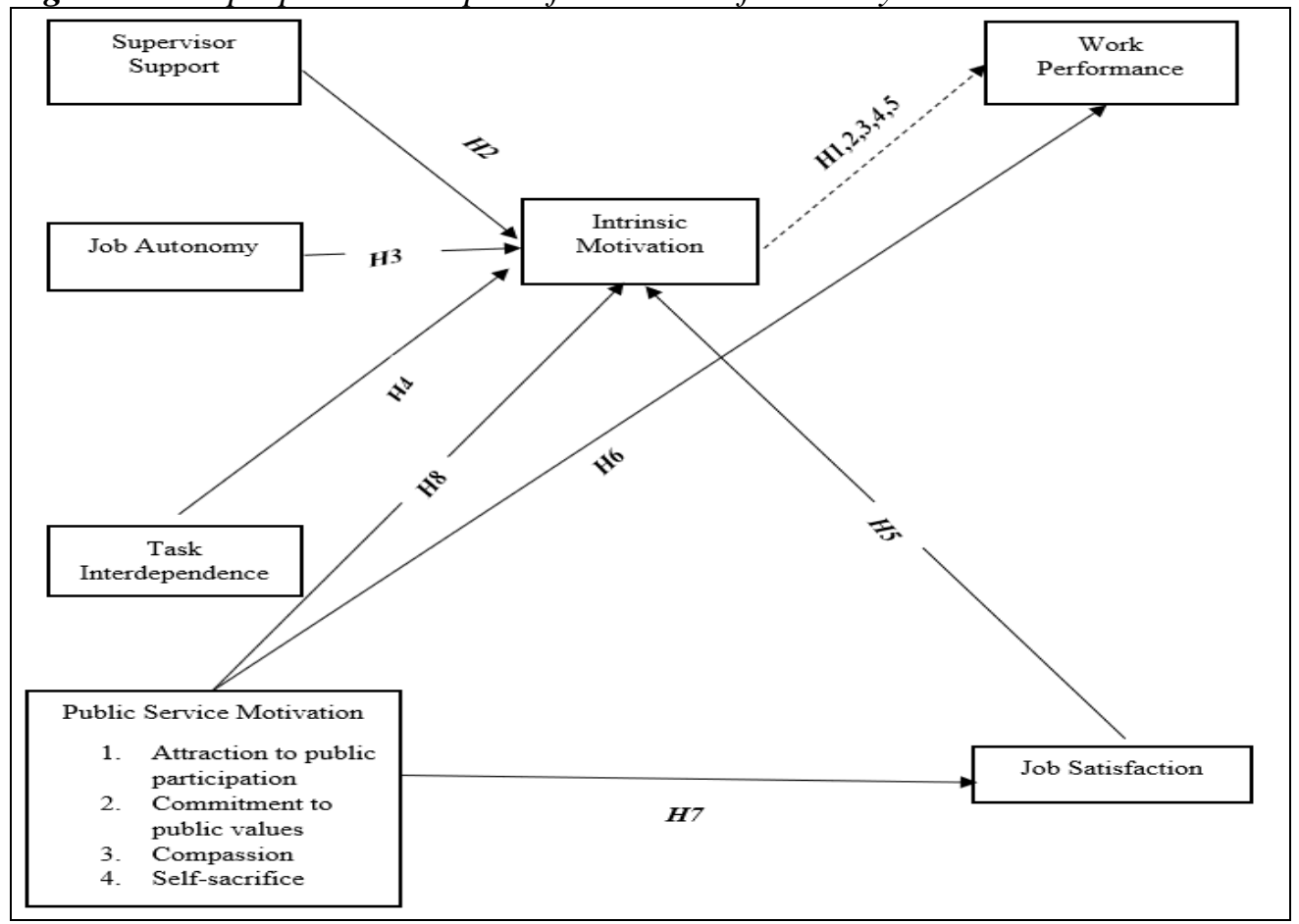




\section{Research Methodology}

\subsection{The Study Population}

An empirical survey, with the use of a newly-developed structured questionnaire, was conducted on a sample of employees working in the public sector (public servants). More specifically, the sampling frame included all the employees of the Hellenic Agricultural Insurance Organization (H.A.I.O.). H.A.I.O. was founded in 1988. It is the principal insurance fund for farmers and provides a full range of insurance protection services. According to the most recent available official data (01-01-2018), 489 employees are currently occupied in H.A.I.O. These employees constitute the sample of this study.

\subsection{Measurement}

The present empirical study includes seven factors, one of which, namely Public Service Motivation (PSM), is measured via four sub-factors (see Figure 1 for more details). As such, ten different constructs (factors) were included in the questionnaire of the empirical survey. All these factors were measured with the use of multiple items (questions) that were adopted from the international literature (see Table 1). A five-point Likert scale was used for the measurement of all factors. All items were translated to Greek and then back to English by another person, in order to detect and consequently eliminate any possible discrepancies.

The structured questionnaire consisted of eleven sections. The first ten were used for measuring the ten factors of the study, while the eleventh included demographic questions about the employee answering the questionnaire.

Table 1. Factor measurement

\begin{tabular}{|c|c|c|}
\hline Dimensions & No of items & Sources \\
\hline \multicolumn{3}{|l|}{ Basic physiological needs } \\
\hline 1. Supervisor support & 10 & $\begin{array}{l}\text { Kim (2005); Martinsen (2005); } \\
\text { Kuvaas (2008) }\end{array}$ \\
\hline 2. Job autonomy & 8 & $\begin{array}{l}\text { Morgeson and Humphrey (2006); Kuvaas } \\
\text { (2008); Dysvik and Kuvaas (2011) }\end{array}$ \\
\hline 3. Task interdependence & 5 & $\begin{array}{l}\text { Morgeson and Humphrey (2006); } \\
\text { Kuvaas (2008) }\end{array}$ \\
\hline 4. Intrinsic motivation & 5 & $\begin{array}{l}\text { Cameron and Pierce (1994); Kuvaas } \\
\text { (2006, 2008); Dysvik et al. (2013); } \\
\text { Belle (2014) }\end{array}$ \\
\hline \multicolumn{3}{|l|}{ Public Service Motivation } \\
\hline $\begin{array}{l}\text { 5. Attraction to public } \\
\text { participation }\end{array}$ & 4 & \multirow{3}{*}{$\begin{array}{l}\text { Kim et al. (2012); } \\
\text { Breaugh } \text { et al. }(2017)\end{array}$} \\
\hline $\begin{array}{l}\text { 6. Commitment to public } \\
\text { values }\end{array}$ & 4 & \\
\hline 7. Compassion & 4 & \\
\hline
\end{tabular}




\begin{tabular}{|l|l|l|}
\hline 8. Self-sacrifice & 4 & \\
\hline Job effects & 6 & $\begin{array}{l}\text { Pettit } \text { et al. (1997); Fang Liu } \text { et al. (2017); } \\
\text { Yun and Lee (2017) }\end{array}$ \\
\hline 9. Job performance & 6 & Mason (1995); Kim (2005) \\
\hline 10. Job satisfaction & 6
\end{tabular}

\subsection{Data Collection}

As mentioned earlier, primary data were collected from a sample of public servants (employees of the Hellenic Agricultural Insurance Organization, H.A.I.O.). Contact information concerning the 489 employees of the H.A.I.O. (email addressees and company telephone numbers) was officially obtained from the management of the Organization. Totally, 390 employees were approached and informed to participate in the survey.

The questionnaire was uploaded online (using Google drive) and the link sent electronically to the 390 employees. The survey lasted two months (December 2018 and January 2019). After the completion of this process, 178 questionnaires were returned and after conducting all necessary controls, 174 usable questionnaires were finally remained and used for data analysis. The response rate is $44,6 \%$, consistent with previous studies of the same research field.

\subsection{Validity and Reliability}

The research instrument was tested for its content and construct validity. The test for the content validity was conducted prior to the empirical survey. More specifically, the instrument was discussed in a series of in-depth interviews with experienced academics and professionals. All proposed modifications were fully incorporated and the research instrument was crystallized.

For the examination of the construct validity, each of the appropriate ten research factors was evaluated for its unidimensionality and reliability. The estimation of the unidimensionality was conducted using Exploratory Factor Analysis (EFA) with Principal Component Analysis (Hair et al., 1995; Straub, 1989). Moreover, cronbach alpha was used to measure the reliability of the measurement scales (Nunnally, 1978). All tests concluded that the scales used are valid and reliable (see Table 2 for the main results).

Furthermore, the evaluation of the goodness of fit of each of the research factors was conducted using Confirmatory Factor Analysis (CFA). All tests conducted produced satisfactory results (see Table 3 above for the main results). More specifically, the following measures have been examined (Schumacker and Lomax, 2010):

- $\mathrm{X}^{2}$ : It should be statistically insignificant $(\mathrm{p}>0,05)$.

- Normed $\mathrm{X}^{2}\left(\mathrm{X}^{2} / \mathrm{df}\right)$ : Values between 1 and 3 are desirable, while values between 1 and 5 are acceptable. 
- Construct Reliability (C.R.): It should higher than 0,7.

- Variance Extracted (V.E.): It should higher than $50 \%$.

- RMSEA: It should be less than 0,1.

- CFI / GFI: They both should be higher than 0,9 .

Table 2. Estimation of unidimensionality and reliability

\begin{tabular}{|l|l|l|l|l|l|}
\hline Factors & KMO & $\begin{array}{l}\text { Bartlett's } \\
\text { Test of } \\
\text { Sphericity }\end{array}$ & $\begin{array}{l}\text { Eigen- } \\
\text { value }\end{array}$ & $\begin{array}{l}\text { Total } \\
\text { Variance } \\
\text { Explaine } \\
\text { d }\end{array}$ & $\begin{array}{l}\text { Cronbach } \\
\text { Alpha }\end{array}$ \\
\hline 1. Supervisor support & 0,786 & $89,5^{*}$ & 2,564 & $79,9 \%$ & 0,77 \\
\hline 2. Job autonomy Task & 0,852 & $91,9^{*}$ & 2,154 & $81,6 \%$ & 0,79 \\
\hline $\begin{array}{l}\text { 3. Intrinsic } \\
\text { interdependence }\end{array}$ & 0,763 & $66,2^{*}$ & 2,941 & $74,3 \%$ & 0,81 \\
\hline $\begin{array}{l}\text { 4. motivation } \\
\text { m. Attraction to public }\end{array}$ & 0,911 & $69,3^{*}$ & 2,811 & $79,6 \%$ & 0,77 \\
\hline $\begin{array}{l}\text { 5articipation } \\
\text { 6. Commitment to } \\
\text { public values }\end{array}$ & 0,861 & $73,8^{*}$ & 2,739 & $72,6 \%$ & 0,91 \\
\hline 7. Compassion & 0,761 & $67,9^{*}$ & 1,971 & $69,4 \%$ & 0,84 \\
\hline 8. Self-sacrifice & 0,889 & $71,2^{*}$ & 2,947 & $75,9 \%$ & 0,75 \\
\hline $\begin{array}{l}\text { (5-8) } \\
\text { Second-order EFA }\end{array}$ & 0,811 & $67,5^{*}$ & 3,511 & 74,3 & 0,81 \\
\hline 9. Job performance & 0,716 & $76,3^{*}$ & 1,637 & $82,1 \%$ & 0,76 \\
\hline 10. Job satisfaction & 0,863 & $39,9^{*}$ & 3,245 & $81,9 \%$ & 0,81 \\
\hline *p<0,01 & & & & & \\
\hline
\end{tabular}

Table 3. Estimation of the goodness of fit

\begin{tabular}{|l|l|l|l|l|l|l|}
\hline Factors & $\begin{array}{l}\text { Norme } \\
\mathbf{d ~ X}^{\mathbf{2}}\end{array}$ & $\mathbf{C . R .}$ & V.E. & RMSEA & CFI & GFI \\
\hline 1. Supervisor support & 3,74 & 0,87 & $66,6 \%$ & 0,075 & 0,91 & 0,99 \\
\hline 2. Job autonomy Task & 2,66 & 0,79 & $69,5 \%$ & 0,051 & 0,97 & 0,99 \\
\hline $\begin{array}{l}\text { 3. } \\
\text { interdependence }\end{array}$ & 1,95 & 0,82 & $73,0 \%$ & 0,063 & 0,99 & 0,98 \\
\hline $\begin{array}{l}\text { 4. Intrinsic } \\
\text { motivation }\end{array}$ & 2,38 & 0,82 & $71,6 \%$ & 0,057 & 0,94 & 0,95 \\
\hline $\begin{array}{l}\text { 5. Attraction to public } \\
\text { participation }\end{array}$ & 3,59 & 0,76 & $66,2 \%$ & 0,044 & 0,96 & 0,96 \\
\hline $\begin{array}{l}\text { 6. Commitment to } \\
\text { public values }\end{array}$ & 3,76 & 0,79 & $61,3 \%$ & 0,034 & 0,99 & 0,97 \\
\hline 7. Compassion & 2,11 & 0,82 & $58,9 \%$ & 0,058 & 0,94 & 0,91 \\
\hline 8. Self-sacrifice & 3,49 & 0,88 & $61,3 \%$ & 0,081 & 0,91 & 0,93 \\
\hline $\begin{array}{l}\text { 5-8) } \\
\text { Second-order CFA }\end{array}$ & 3,58 & 0,76 & $67,3 \%$ & 0,056 & 0,97 & 0,97 \\
\hline 9. Job performance & 1,81 & 0,84 & $77,8 \%$ & 0,071 & 0,97 & 0,98 \\
\hline 10. Job satisfaction & 2,66 & 0,77 & $59,6 \%$ & 0,066 & 0,99 & 0,99 \\
\hline
\end{tabular}


It should be also mentioned that concerning the four sub-factors measuring Public Service Motivation (PSM), namely (a) Attraction to public participation, (b) Commitment to public values, (c) Compassion, (d) Self-sacrifice, a second-order Factor Analysis (second order EFA and CFA) was additionally performed, since the development of a hyper-construct (PSM) was necessary for testing Hypotheses 6, 7 and 8.

\section{Empirical Findings}

The examination of the proposed conceptual framework (empirical test of research hypotheses) was conducted with the use of the Structural Equation Modeling (SEM) technique. More specifically, the Maximum Likelhood Estimation method was employed, the Covariance Matrix was used as the table of entry, and the extraction of the Standardized Completely Solution was requested (Kelloway, 1998; Hair et al., 1995).

In more detail, the (modified) structural model fitted the data well, while the factors that were included could sufficiently explain the variance of the dependent factors. It must be noted that new paths were added to the model, based on the modification indexes of the statistical package IBM AMOS. This resulted in a structural model with improved fit and explanatory power. Figure 2 demonstrates the modified structural model, with the extracted path coefficients and the adjusted $\mathrm{R}^{2}$ scores.

More analytically, in order to evaluate the fit of the overall model, the chi-square value $\left(\chi^{2}=56,41\right.$ with 18 degrees of freedom) and the $p$-value $(p=0,026)$ were estimated. These values indicate a satisfactory fit of the data to the overall model. However, the sensitivity of the $\chi^{2}$ statistic to the sample size forces towards the adoption of other supplementary measures for evaluating the overall model (Smith

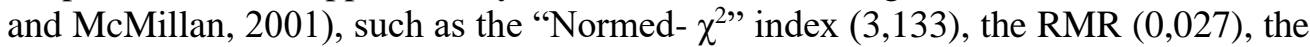
CFI $(0,974)$, the GFI $(0,952)$, and the RSMEA $(0,044)$, that all indicate a very good fit.

Table 4 demonstrates, among others, the model fit summary and the findings concerning the hypotheses of the study, while Table 5 summarizes the Total, Direct, and Indirect effects between the research factors that were incorporated into the proposed research model.

The results of the statistical analysis provide support to five out of the eight initial hypotheses, while three new casual paths were added to the model (after consulting the modification indexes provided by IBM AMOS). All the additional casual paths are concerned with indirect relationships, in which job autonomy and job satisfaction act as mediating factors [e.g., Job autonomy (via Job satisfaction) $\rightarrow$ Intrinsic motivation]. Finally, Hypothesis 2 [Supervisor support (via Intrinsic motivation) $\rightarrow$ Job performance], Hypothesis 4 [Task interdependence (via Intrinsic motivation) $\rightarrow$ Job performance] and Hypothesis 8 (Public Service Motivation $\rightarrow$ Intrinsic motivation) were rejected by the empirical data. 
Factors Affecting Motivation in the Public Sector under the Context of STD and PSM:

The Case of the Hellenic Agricultural Insurance Organization (H.A.I.O.)

Table 4. Hypotheses testing results

\begin{tabular}{|l|l|}
\hline \multicolumn{2}{|l|}{ Model Fit Summary } \\
\hline Normed- $\chi^{2}$ & 3,133 \\
\hline RMR & 0,027 \\
\hline CFI & 0,974 \\
\hline GFI & 0,952 \\
\hline RMSEA & 0,044 \\
\hline
\end{tabular}

\begin{tabular}{|l|l|}
\hline Squared Multiple Correlations $\left(\mathbf{R}^{\mathbf{2}}\right)$ \\
\hline & Estimate \\
\hline Job autonomy & $0,240 / 24 \%$ \\
\hline Job performance & $0,130 / 13 \%$ \\
\hline Intrinsic motivation & $0,276 / 28 \%$ \\
\hline Job satisfaction & $0,208 / 21 \%$ \\
\hline
\end{tabular}

\begin{tabular}{|l|l|l|l|l|}
\hline $\mathbf{H}$ & Causal path & $\mathbf{r}$ & $\mathbf{p}$ & Remarks \\
\hline $\boldsymbol{H 1}$ & Intrinsic motivation $\rightarrow$ Job performance & 0,168 & 0,000 & Accepted \\
\hline $\boldsymbol{H 2}$ & $\begin{array}{l}\text { Supervisor support (via Intrinsic motivation) } \\
\text { Job performance }\end{array}$ & - & $*$ & Rejected \\
\hline $\boldsymbol{H 3}$ & $\begin{array}{l}\text { Job autonomy (via Intrinsic motivation) } \rightarrow \\
\text { Job performance }\end{array}$ & 0,056 & $* *$ & Accepted \\
\hline $\boldsymbol{H 4}$ & $\begin{array}{l}\text { Task interdependence (via Intrinsic motivation) } \\
\text { Job performance }\end{array}$ & - & $* * *$ & Rejected \\
\hline $\boldsymbol{H 5}$ & $\begin{array}{l}\text { Job satisfaction (via Intrinsic motivation) } \rightarrow \\
\text { Job performance }\end{array}$ & 0,053 & $* *$ & Accepted \\
\hline H6 & Public Service Motivation $\rightarrow$ Job performance & 0,156 & 0,031 & Accepted \\
\hline $\boldsymbol{H 7}$ & Public Service Motivation $\rightarrow$ Job satisfaction & 0,163 & 0,017 & Accepted \\
\hline $\boldsymbol{H 8}$ & Public Service Motivation $\rightarrow$ Intrinsic motivation & 0,013 & 0,265 & Rejected \\
\hline
\end{tabular}

\section{Proposed causal relationships}

\begin{tabular}{|c|c|c|c|c|}
\hline & $\begin{array}{l}\text { Supervisor support (via Job autonomy) - } \\
\text { Job performance }\end{array}$ & 0,103 & $* *$ & New path \\
\hline & $\begin{array}{l}\text { Supervisor support (via Job satisfaction) - } \\
\text { Intrinsic motivation }\end{array}$ & 0,016 & $* *$ & New path \\
\hline & $\begin{array}{l}\text { Job autonomy (via } \\
\text { Intrinsic motivation }\end{array}$ & 0,009 & $* *$ & New path \\
\hline $\begin{array}{l}* \\
* * * * \\
* * * *\end{array}$ & $\begin{array}{l}\text { Only one path is statistically significant } \\
\text { Both paths are statistically significant } \\
\text { The factor "Task interdependence" has been removed }\end{array}$ & & & \\
\hline
\end{tabular}

Overall, results underline the significant role of job autonomy and job satisfaction and their impact on the intrinsic motivation of employees. The proposed model successfully captured the causal relationships between the various research factors and it can be considered as a starting point for future research. The main results of this study are summarized below: 
Figure 2. The modified structural model (all paths are significant)

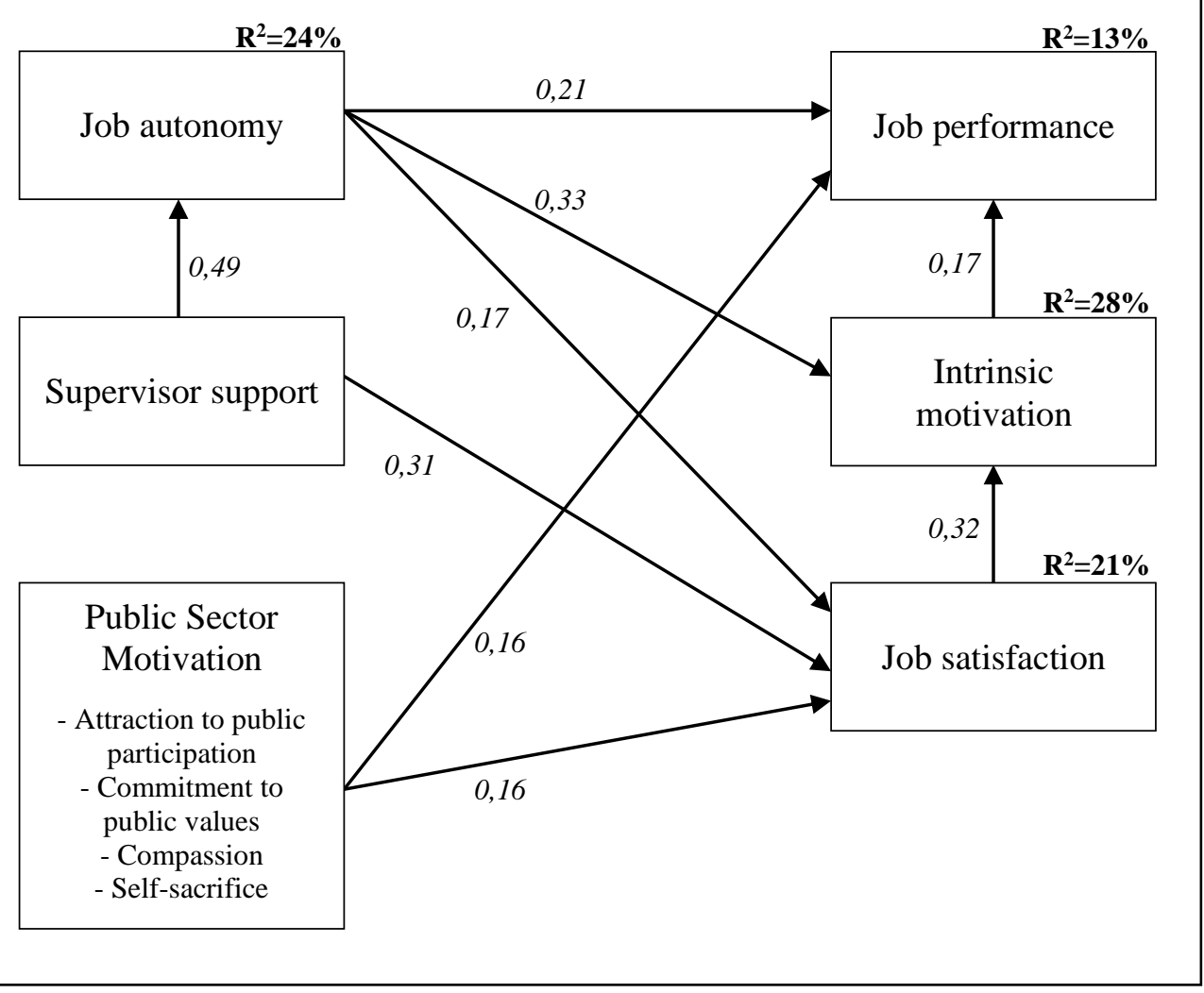

Table 5. Direct, Indirect and Total standardised effects between research factors

\begin{tabular}{|l|l|l|l|l|l|l|}
\hline & & $\begin{array}{l}\text { Supervisor } \\
\text { support }\end{array}$ & $\begin{array}{l}\text { Public } \\
\text { Service } \\
\text { Motivation }\end{array}$ & $\begin{array}{l}\text { Job } \\
\text { autonomy }\end{array}$ & $\begin{array}{l}\text { Job } \\
\text { atisfaction }\end{array}$ & $\begin{array}{l}\text { Intrinsic } \\
\text { motivation }\end{array}$ \\
\hline \hline \multirow{2}{*}{$\begin{array}{l}\text { Job } \\
\text { autonomy }\end{array}$} & Direct & 0,490 & - & - & - & - \\
\cline { 2 - 7 } & Indirect & - & - & - & - & - \\
\cline { 2 - 7 } & Total & 0,490 & - & - & - & - \\
\hline \hline \multirow{3}{*}{$\begin{array}{l}\text { Job } \\
\text { satisfaction }\end{array}$} & Direct & 0,312 & 0,163 & 0,174 & - & - \\
\cline { 2 - 7 } & Indirect & 0,085 & - & - & - & - \\
\cline { 2 - 7 } $\begin{array}{l}\text { Intrinsic } \\
\text { motivation }\end{array}$ & Total & 0,397 & 0,163 & 0,174 & - & - \\
\cline { 2 - 7 } & Direct & - & - & 0,329 & 0,316 & - \\
\cline { 2 - 7 } & Indirect & 0,287 & 0,052 & 0,055 & - & - \\
\hline \hline \multirow{2}{*}{$\begin{array}{l}\text { Job } \\
\text { performanc } \\
\text { e }\end{array}$} & Direct & 0,287 & 0,052 & 0,384 & 0,316 & - \\
\cline { 2 - 7 } & Indirect & 0,151 & 0,009 & 0,065 & 0,053 & - \\
\cline { 2 - 7 } & Total & 0,151 & 0,164 & 0,275 & 0,053 & 0,168 \\
\hline \hline
\end{tabular}


- The predictive power of the modified model is satisfactory, since it agrees with the findings of various previous studies of the field. For example, Kuvaas (2008) developed a model that explained $14 \%$ of the variance in job performance and $25 \%$ of the variance in intrinsic motivation. Numerous other authors (e.g., Taylor, 2008; Kim, 2012; Vandenabeele, 2014; Brewer and Selden, 2000; Manolopoulos, 2008) found similar results.

- Task interdependence was not found to have any effect, direct or indirect, on job performance. Therefore, it was removed from the modified structural model.

- Intrinsic motivation directly influences Job performance $(\mathrm{r}=0,17)$ and along with Job autonomy and Public Sector Motivation can predict 13\% of its variance. Hence, Hypothesis 1 is verified.

- Job autonomy affects Job performance, both directly $(\mathrm{r}=0,21)$ and indirectly (via Intrinsic motivation) $(\mathrm{r}=0,06)$. Hence, Hypothesis 3 is verified.

- Job satisfaction indirectly affects, via Intrinsic motivation, Job performance $(\mathrm{r}=0,05)$, supporting Hypothesis 5.

- Public Sector Motivation directly affects Job performance ( $\mathrm{r}=0,16)$, also offering support for Hypothesis 6.

- Moreover, Public Sector Motivation, along with Job autonomy and Supervisor support, can predict $21 \%$ of the variance in Job satisfaction. Under that context, Hypothesis 7 is also supported.

- Supervisor support directly affects Job autonomy $(r=0,49)$. This is, actually, the stronger relationship of the research model. Also, Supervisor support indirectly affects Job performance $(r=0,10)$, via Job autonomy. Therefore, the relationship between Supervisor support and Job performance is largely mediated through Job autonomy.

- Also, the relationship between Supervisor support and Intrinsic motivation if mediated through Job satisfaction. Additionally, the direct impact of Supervisor support on Job satisfaction is quite strong $(\mathrm{r}=0,31)$.

- Finally, the relationship between Job autonomy and Intrinsic motivation seems to be both direct $(\mathrm{r}=0,33)$ and indirect $(\mathrm{r}=0,05)$, mediated though Job satisfaction. Taking under consideration both direct and indirect effects, Job autonomy, quite interestingly, has the stronger total impact on Job performance $(r=0,275)$.

\section{Conclusions}

The present study aimed to develop and empirically test an original conceptual framework that investigates employee motivation, in the light of two prominent theories, the Self Determination Theory (SDT), and the Public Service Motivation (PSM). The factors included in the proposed conceptual framework fall into various dimensions. Such a multidimensional approach has never been explored in the existing literature of the field, making the examination of the proposed conceptual framework an interesting research topic.

The examination of the proposed conceptual framework was made with the use of a newly developed structured questionnaire. The questionnaire was distributed to the 
employees of a specific Greek public organization [Hellenic Agricultural Insurance Organization, H.A.I.O.]. The questionnaire, consisting of items (questions) measuring ten research factors (constructs), was targeted to 390 public servants. After the completion of the two month data collection period, 174 usable questionnaires were remained (response rate $=44,6 \%$ ). The Structural Equation Modeling technique was used in order to test the research hypothesis of this study.

Empirical results underline the significant impact of four research factors (namely, Supervisor support, Public Service Motivation, Job satisfaction, Intrinsic motivation) on Job performance. Moreover, the multifaceted role of Job autonomy is highlighted, arguing that public servants value their autonomy in the workplace. According to the empirical results, job performance is being influenced both directly and indirectly; it seems that enhancing employee performance in public organizations is a demanding task. In a hierarchical order, Job autonomy is the most significant determinant of job performance, while the second place is occupied equally by the three other factors (Supervisor support, Public Service Motivation, Job satisfaction). Surprisingly, the impact of Job satisfaction on Job performance is not as strong as these ones.

Overall, the present study argues in favor of intrinsic motivation in the public sector. When external incentives that can be offered to employees are limited, it is crucial to consider the importance of promoting and supporting intrinsic motivation. Moreover, results strongly support the self-determination theory, suggesting that public servants appreciate autonomy-supportive work environments. That finding is consistent with those of previous relevant studies.

Three are the main limitations of the study. Firstly, it concerns a case study of a single public Organization and therefore it may affect the generalizability of the results. In order to generalize the findings of the present research, attention is needed to be paid to all public sector Organizations, where HRM reforms are likely to be more mature and HR managers are more familiar with these incentives. Secondly, as 'motivations' are not 'fixed' characteristics and vary over time and according to different circumstances, this research is considered as a static one and does not constitute a longitudinal analysis in order to obtain reliable evidence on the role of motivation in performance in the long run. Thirdly, attention should be paid to the reliance on self-reported questionnaire data. Furhter research is suggested to be performed in similar Orgnizatios in Greece or internationally, and particularly in more stable economic envirnments.

\section{References:}

Alonso, P. and Lewis, G.B. 2001. Public service motivation and job performance: evidence from the federal sector. American Review of Public Administration, Vol. 31, Issue 4, pp. 363-380.

Andersen, L.B. and Serritzlew, S. 2012. Does public service motivation affect the behavior of professionals? International Journal of Public Administration, Vol. 35, Issue 1, 19-29. 
Andersen, L.B., Heinesen, E. and Pedersen, L.H. 2014. How does public service motivation among teachers affect student performance in schools? Journal of Public Administration Research and Theory, Vol. 24, Issue 3, 651-671.

Andersen, L.B., Heinesen, E. and Pedersen, L.H. 2016. Individual Performance: From common source bias to institutionalized assessment. Journal of Public Administration Research and Theory, Vol. 26, Issue 1, pp. 63-78.

Andrews, C. 2016. Integrating public service motivation and self-determination theory: A framework. International Journal of Public Sector Management, 29, Issue 3, 238-254.

Andrews, C.W., Rezende, S. and Almeida, W.M. 2015. Delivering education to the poor: Investigating the role of self-motivation in Brazil. International Review of Administrative Sciences, Vol. 83, Issue 3, pp. 524-540.

Baard, P.P., Deci E.L. and Ryan, RM. (2004. Intrinsic need satisfaction: A motivational basis of performance and well-being in two work settings. Journal of Applied Social Psychology, Vol. 34, Issue 10, 2045-2068.

Bachrach, D.G., Powell, B.C., Bendoly, E. and Richey, R.G. 2006. Organizational citizenship behavior and performance evaluations: exploring the impact of task interdependence. Journal of Applied Psychology, Vol. 91, Issue 1, pp. 193-201.

Barron, R.A. 1983. Behaviour in organizations. Allyn \& Bacon, Inc., New York.

Bellé, N. 2013. Experimental evidence on the relationship between public service motivation and job performance. Public Administration Review, Vol. 73, Issue 1, pp. 143-153.

Bellé, N. 2014. Leading to make a difference: A field experiment on the performance effects of transformational leadership, perceived social impact, and public service motivation. Journal of Public Administration Research and Theory, Vol. 24, Issue 1, pp. 109-136.

Bellé, N. and Cantarelli, P. 2012. Public service motivation: The state of the art. In Tria, G. and Valotti, G. Reforming the Public Sector: How to Achieve Better Transparency, Service, and Leadership, 96-125. Brookings Institution Press, Washington, D.C.

Berman, E.M., Bowman, J.S., West, J.P. and Van Wart, M.R. 2010. Human resource management in public services: Paradoxes, processes, and problems, (3rd edition), Sage, Thousand Oaks, CA.

Black, A.E. and Deci, E.L. 2000. The effects of instructors' autonomy support and students' autonomous motivation on learning organic chemistry: A self-determination theory perspective. Science Education, Vol. 84, Issue 6, pp. 740-756.

Bono, J.E. and Judge, T.A. 2003. Self-concordance at work: understanding the motivational effects of transformational leaders. Academy of Management Journal, 46, 5, 554-571.

Breaugh, J., Ritz, A. and Alfes, K. 2017. Work motivation and public service motivation: disentangling varieties of motivation and job satisfaction. Public Management Review, Vol. 20, Issue 10, pp. 1423-1443.

Brewer, G.A. 2008. Employee and organizational performance. In Perry, J.L. and Hondeghem, A. (eds), Motivation in Public Management: The Call of Public Service, pp. 136-56, Oxford University Press, Oxford.

Brewer, G.A. and Selden, S.C. 1998. Whistle blowers in the Federal civil service: New evidence of the public service ethic. Journal of Public Administration Research and Theory, Vol. 8, Issue 3, pp. 413-439.

Brewer, G.A. and Selden, S.C. 2000. Why elephants gallop: Assessing and predicting organizational performance in federal agencies. Journal of Public Administration Research and Theory, Vol. 10, Issue 4, pp. 685-712.

Brewer, G.A., Selden, S.C., Facer, I.I. and Rex, L. 2000. Individual conceptions of public service motivation. Public Administration Review, Vol. 60, Issue 3, pp. 254-264. 
Bright, L. 2007. Does person-organization fit mediate the relationship between public service motivation and the job performance of public employees? Review of Public Personnel Administration, Vol. 27, Issue 4, pp. 361-379.

Bright, L. 2008. Does public service motivation really make a difference on the job satisfaction and turnover intentions of public employees? The American Review of Public Administration, Vol. 38, Issue 2, pp. 149-166.

Cameron, J. and Pierce, W.D. 1994. Reinforcement, reward, and intrinsic motivation: a metaanalysis. Review of Educational Research, Vol. 64, Issue 3, pp. 363-423.

Camilleri, E. 2007. Antecedents affecting public service motivation. Personnel Review, Vol. 36, Issue 3, pp. 356-377.

Deci, E.L. and Ryan, R.M. 1985. Intrinsic Motivation and Self-Determination in Human Behavior, Plenum Press, New York.

Deci, E.L., Connell, J.P. and Ryan, R.M. 1989. Self-determination in a work organization. Journal of Applied Psychology, Vol. 74, Issue 4, pp. 580-590.

Deci, E.L., Olafsen, A.H. and Ryan, R.M. 2017. Self-determination theory in work organizations: The state of a science. Annual Review of Organizational Psychology and Organizational Behavior, Vol. 4, Issue 1, pp. 19-43.

Deci, E.L., Ryan, R.M., Gagné, M., Leone, D.R., Usunov, J. and Kornazheva, B.P. 2001. Need satisfaction, motivation, and well-being in the work organizations of a former Eastern Bloc country. Personality and Social Psychology Bulletin, 27, 8, 930- 942.

Dilulio, J.D. 1994. Principles agents: The cultural bases of behavior in a federal government bureaucracy. Journal of Public Administration Research and Theory, 4, 3, 277-318.

Dysvik, A. and Kuvaas, B. 2011. Intrinsic motivation as a moderator on the relationship between perceived job autonomy and work performance. European Journal of work and organizational psychology, Vol. 20 Issue 3, pp. 367-387.

Dysvik, A., Kuvaas, B. and Gagne, M. 2013. An investigation of the unique, synergistic and balanced relationships between basic psychological needs and intrinsic motivation. Journal of Applied Social Psychology, Vol. 43, Issue 5, pp. 1050-1064.

Eisenberger, R., Stinglhamber, F., Vandenberghe, C., Sucharski, I.L. and Rhoades, L. 2002. Perceived supervisor support: Contributions to perceived organizational support and employee retention. Journal of Applied Psychology, Vol. 87, Issue 3, pp. 565-573.

Erven, B. and Milligan, R. 2001. Making employee motivation a partnership. Proceedings Employee Management for Production Agriculture Conference. Kansas State University.

Fang Liu, F., Chow, I.H., Xiao, D. and Huang, M. 2017. Cross-level effects of HRM bundle on employee well-being and job performance: The mediating role of psychological ownership. Chinese Management Studies, Vol. 11, Issue 3, 520-537.

Fernet, C., Trépanier, S.G., Austin, S., Gagné, M. and Forest, J. 2015. Transformational leadership and optimal functioning at work: On the mediating role of employees' perceived job characteristics and motivation. Work \& Stress, 29, Issue 1, pp. 11-31.

Gagné, M. and Deci, E. 2005. Self-determination theory and work motivation. Journal of Organizational Behavior, Vol. 26, Issue 4, pp. 331-362.

Gagné, M., Senécal, C. and Koestner, R. 1997. Proximal job characteristics, feelings of empowerment, and intrinsic motivation: A multidimensional model. Journal of Applied Social Psychology, Vol. 27, Issue 14, pp. 1222-1240.

Gefen, D., Straub, D. and Boudreau, M.C. 2000. Structural equation modeling and regression: Guidelines for research practice. Communications of the F Association for Information Systems, Vol. 4, Issue 1, Article 7. 
Gillet, N., Gagné, M., Sauvagère, S. and Fouquereau, E. 2013. The role of supervisor autonomy support, organizational support, and autonomous and controlled motivation in predicting employees' satisfaction and turnover intentions. European Journal of Work and Organizational Psychology, Vol. 22, Issue 4, pp. 450-460.

Gould-Williams, J.S., Mostafa, A.M.S. and Bottomley, P. 2015. Public service motivation and employee outcomes in the Egyptian public sector: Testing the mediating effect of person-organization fit. Journal of Public Administration Research and Theory, Vol. 25 Issue 2, pp. 597-622.

Grant, A.M. 2008. Does intrinsic motivation fuel the prosocial fire? Motivational synergy in predicting persistence, performance and productivity. Journal of Applied Psychology, Vol. 93, Issue 1, pp. 48-58.

Graves, L.M., Cullen, K.L., Lester, H.F., Ruderman, M.N. and Gentry, W.A. 2015. Managerial motivational profiles: Composition, antecedents, and consequences. Journal of Vocational Behavior, Vol. 87, Issue 1, pp. 32-42.

Grolnick, W.S. and Ryan, R,M. 1987. Autonomy in children's learning: an experimental and individual difference investigation. Journal of Personality and Social Psychology, Vol. 52, Issue 5, pp. 890-898.

Hair, F., Anderson, R., Tatham, R. and Black, W. 1995. Multivariate Data Analysis with Readings. Prentice-Hall International, London.

Hardré, P.L. and Reeve, J. 2009. Training corporate managers to adopt a more autonomysupportive motivating style toward employees: an intervention study. International Journal of Training and Development, Vol. 13, Issue 3, pp. 165-184.

Howard, J., Gagné, M., Morin, A.J.S. and Van den Broeck, A. 2016. Motivation profiles at work: A self-determination theory approach. Journal of Vocational Behavior, Vol. 9596, pp. 74-89.

Ilardi, B.C., Leone, D., Kasser, T. and Ryan, R.M. 1993. Employee and supervisor ratings of motivation: Main effects and discrepancies associated with job satisfaction and adjustment in a factory setting. Journal of Applied Social Psychology, 23, 21, 17891805 .

Judge, T.A., Thoresen, C.J., Bono, J.E. and Patton, G.K. 2001. The job satisfaction job performance relationship: a qualitative and quantitative review. Psychological Bulletin, Vol. 127, Issue 3, pp. 376-407.

Kalliga, A. 2011. Motivating employees in the public sector during periods of crisis. National School of Local Administration, Athens [in Greek].

Kelloway, E.K. 1998. Using LISREL for structural equation modeling: A researcher's guide. Sage Publishing, USA.

Kelly, J.E. 1974. Organizational Behavior. Richard D. Irwin, Homewood.

Kelly, J.E. 1992. Does job re-design theory explain job re-design outcomes? Human Relations, Vol. 45, Issue 8, pp. 753-74.

Kim, S. 2005. Individual-level factors and organizational performance in government organizations. Journal of Public Administration Research and Theory, 15, 2, 245-261.

Kim, S. 2011. Testing a revised measurement of public service motivation: Reflective versus formative specification. Journal of Public Administration Research and Theory, Vol. 21, Issue 3, pp. 521-546.

Kim, S. 2012. Does Person-organization fit matter in the public-sector? Testing the mediating effect of Person-organization fit in the relationship between public service. Public Administration Review, Vol. 72, Issue 6, pp. 830-840.

Kim, S., Vandenabeele, W., Wright, B.E., Andersen, L.B., Cerase, F.P., Christensen, R.K., Desmarais, C., Koumenta, M., Leisink, P., Liu, B., Palidauskaite, J., Pedersen, L.H., 
Perry, J.L., Ritz, A., Taylor, J. and De Vivo, P. 2012. Investigating the Structure and Meaning of Public Service Motivation across Populations: Developing an International Instrument and Addressing Issues of Measurement Invariance. Journal of Public Administration Research and Theory, Vol. 23, Issue 1, pp. 79-102.

Kuvaas, B. 2006. Performance appraisal satisfaction and employee outcomes: mediating and moderating roles of motivation. The International Journal of Human Resource Management, Vol. 17, Issue 3, pp. 504-522.

Kuvaas, B. 2008. A test of hypotheses derived from self-determination theory among public sector employees. Employee Relations, Vol. 31, Issue 1, pp. 39-56.

Kuvaas, B., Buch, P., Weibel, A., Dysvik, A. and Nerstad, C. 2017. Do intrinsic and extrinsic motivation relate differently to employee outcomes? Journal of Economic Psychology, Vol. 61, Issue C, pp. 244-258.

Leisink, P.L.M. and Steijn, B. 2009. Public service motivation and job performance of public sector employees in the Netherlands. International Review of Administrative Sciences, Vol. 75, Issue 1, pp. 35-52.

Liu, B., Tang, N. and Zhu, X. 2008. Public service motivation and job satisfaction in China: An investigation of generalisability and instrumentality. International Journal of Manpower, Vol. 29, Issue 8, pp. 684-699.

Manolopoulos, D. 2008. An evaluation of employee motivation in the extended public sector in Greece. Employee Relations, Vol. 30, Issue 1, pp. 63-85.

Martinsen, Ø.L. 2005. Handbok Leder profil. PSI - Assessment AS, Oslo.

Mason, E.S. 1995. Gender differences in job satisfaction. Journal of Social Psychology, Vol. 135, Issue 2, pp. 143-151.

Meyer, J.P., Becker, T.E. and Vandenberghe, C. 2004. Employee commitment and motivation: A conceptual analysis and integrative model. Journal of Applied Psychology, Vol. 89, Issue 6, pp. 991-1007.

Moran, C.M., Diefendorff, J.M., Kim, T.Y. and Liu, Z.Q. 2012. A profile approach to selfdetermination theory motivations at work. Journal of Vocational Behavior, Vol. 81, pp. 354-363.

Morgeson, F.P. and Humphrey, S.E. 2006. The Work Design Questionnaire (WDQ): developing and validating a comprehensive measure for assessing job design and the nature of work. Journal of Applied Psychology, Vol. 91, Issue 6, pp. 1321-1339.

Moynihan, D.P. and Pandey, S.K. 2007. Finding workable levers over work motivation: comparing job satisfaction, job involvement, and organizational commitment. Administration \& Society, Vol. 39, Issue 7, pp. 803-832.

Muraven, M., Gagné, M. and Rosman, H. 2008. Helpful self-control: Autonomy support, vitality, and depletion. Journal of Experimental Social Psychology, Vol. 44, Issue 3, pp. 573-585.

Naff, K.C. and Crum, J. 1999. Working for America: Does public service motivation make a difference? Review of Public Personnel Administration, Vol. 19, Issue 4, pp. 5-16.

Nix, G.A., Ryan, R.M., Manly, J.B. and Deci, E.L. 1999. Revitalization through Selfregulation: The effects of autonomous and controlled motivation on happiness and vitality. Journal of Experimental Social Psychology, Vol. 35, Issue 3, pp. 266-284.

Nunnally, J.C. 1978. Psychometric theory. McGraw-Hill, New York.

Organ, D.W. 1988. Organizational Citizenship Behavior: The Good Soldier Syndrome. Lexington Books, Lexington, MA.

Pandey, S.K. and Stazyk, E.C. 2008. Antecedents and correlates of public service motivation. In Perry, J.L. and Hondeghem, A. (eds.) Motivation in Public Management, 101-117, Oxford University Press, Oxford, UK. 
Park, S.M. and Rainey, H.G. 2012. Work motivation and social communication among public managers. The International Journal of Human Resource Management, Vol. 23, Issue 13, pp. 2630-2660.

Pelletier, L.G., Fortier, M.S., Vallerand, R.J. and Bréire, N.M. 2001. Associations among perceived autonomy support, forms of self-regulation, and persistence: A prospective study. Motivation and Emotion, Vol. 25, Issue 4, pp. 279-306.

Perry, J.L., Hondeghem A. and Wise, L.R. 2010. Revisiting the motivational bases of public service: Twenty years of research and an agenda for the future. Public Administration Review, Vol. 70, Issue 5, pp. 681-690.

Perry, J.L. 1996. Measuring public service motivation: An assessment of construct reliability and validity. Journal of Public Administration Research and Theory, 6, 1, 5-22.

Perry, J.L. and Hondeghem, A. 2008. Motivation in public management: The call of public services. Oxford University Press, Oxford.

Perry, J.L. and Vandenabeele, W. 2015. Public service motivation research: Achievements, challenges, and future directions. Public Administration Review, 75, 5, pp. 692-699.

Perry, J.L. and Wise, L.R. 1990. The motivational bases of public service. Public Administration Review, Vol. 50, Issue 3, pp. 367-373.

Pettit, J.D., Goris, J.R. and Vaught, B.C. 1997. An examination of organizational communication as a moderator of the relationship between job performance and job satisfaction. Journal of Business Communication, Vol. 34, Issue 1, pp. 81-98.

Piccolo, R.F. and Colquitt, J.A. 2006. Transformational leadership and job behaviors: the mediating role of core job characteristics. Academy of Management Journal, Vol. 49. Issue 2, pp. 327-340.

Pinder, C. 2008. Work motivation in organizational Behavior (2nd eds.). Psychology Press, New York.

Podsakoff, P.M., Mackenzie, S.B., Paine, J.B. and Bachrach, G.D. 2000. Organizational citizenship behaviors: A critical review of the theoretical and empirical literature and suggestions for future research. Journal of Management, Vol. 26, Issue 3, 513-563.

Rigby, C.S. and Ryan, R.M. 2018. Self-Determination theory in human resource development: New directions and practical considerations. Advances in Developing Human Resources, Vol. 20, Issue 2, 133-147.

Ritz, A. 2009. Public service motivation and organizational performance in Swiss federal government. International Review of Administrative Sciences, 75, Issue 1, 53-78.

Ritz, A., Brewer, G.A. and Neumann, O. 2016. Public service motivation: A systematic literature review and outlook. Public Administration Review, 76, 3, 414-426.

Robbins, S.P. and Judge, T.A. 2011. Organizational Behavior, Basic concepts and modern approaches. Kritiki Publishing, Athens [in Greek].

Ryan, R.M. and Deci, E.L. 2000. Self-determination theory and the facilitation of intrinsic motivation, social development, and well-being. American Psychologist, 55, 1, 68-78.

Ryan, R.M. and Deci, E.L. 2002. An overview of Self-determination theory: An organismicdialectical perspective. In Handbook of Self-Determination Research, edited by Deci E.L. and Ryan, R.M., 3-33, University of Rochester Press, Rochester NY.

Ryan, R.M. and Deci, E.L. 2008. From ego depletion to vitality: Theory and findings concerning the facilitation of energy available to the self. Social and Personality Psychology Compass, Vol. 2, Issue 2, 702-717.

Ryan, R.M. and Deci, E.L. 2017. Self-Determination Theory: Basic Psychological Needs in Motivation, Development, and Wellness. Guilford Press, New York. 
Ryan, R.M., Kuhl, J. and Deci, E.L. 1997. Nature and autonomy: Organizational view of social and neurobiological aspects of self-regulation in behavior and development. Development and Psychopathology, Vol. 9 Issue 4, pp. 701-728.

Schott, C and Pronk, J.L.J. 2014. Investigating and explaining organizational antecedents of PSM. Evidence based HRM: A Global Forum for Empirical Scholarship, 2, 1, 28-56.

Schumacker, R.E. and Lomax, R.G. 2010. A Beginner's Guide to Structural Equation Modeling. Routledge Academic, New York.

Slemp, G.R., Kern, M.L., Patrick, K.J. and Ryan, R.M. 2018. Leader autonomy support in the workplace: A meta-analytic review. Motivation and Emotion, 42, Issue 5, 706-724.

Smith, T.D., and McMillan, B.F. 2001. A Primer of Model Fit Indices in Structural Equation Modeling. ERIC, Availabe at: https://eric.ed.gov/?id=ED449231.

Steijn, B. 2008. Person-environment fit and public service motivation. International Public Management Journal, Vol. 11, Issue 1, pp. 13-27.

Straub, D.W. 1989. Validating instruments in MIS research. MIS Quarterly, 13, 2, 147-169.

Taylor, J. 2008. Organizational influences, public service motivation and work outcomes: An Australian study. International Public Management Journal, Vol. 11, Issue 1, 67-88.

Vallerand, R.J. and Bissonnette, R. 1992. Intrinsic, extrinsic, and a motivational styles as predictors of behavior: A prospective study. Journal of Personality, 60, 3, 599-620.

Van den Broeck, A., Lens, W., De Witte, H. and Van Coillie, H. 2013. Unraveling the importance of the quantity and the quality of workers' motivation for well-being: A person-centered perspective. Journal of Vocational Behavior, Vol. 82, Issue 1, 69-78.

Vandenabeele, W. 2007. Toward a public administration theory of public service motivation. Public Management Review, Vol. 9, Issue 4, pp. 545-556.

Vandenabeele, W. 2008. Development of a public service motivation measurement scale: Corroborating and extending Perry's measurement instrument. International Public Management Journal, Vol. 11, Issue 1, pp. 143-167.

Vandenabeele, W. 2009. The mediating effect of job satisfaction and organizational com mitment on self-reported performance: More robust evidence of the PSM-performance relationship. International Review of Administrative Sciences, 75(1), 11-34.

Vandenabeele, W. 2014. Explaining Public Service Motivation, the role of leadership and basic needs satisfaction. Review of Public Personnel Administration, 34, 2, 153-173.

Vandenabeele, W., Brewer, G.A. and Ritz, A. 2014. Past, present, and future of public service motivation research. Public Administration, Vol. 92, Issue 4, pp. 779-789.

Weiss, H. 2002. Deconstructing Job Satisfaction. Separating Evaluations, Beliefs and Affective Experiences. Human Resource Management Review, 12, 2, pp. 173-194.

Wilkesmann, U. and Schmid, C.J. 2014. Intrinsic and internalized modes of teaching motivation. Evidence-based HRM: A Global Forum for Empirical Scholarship, Vol. 2 Issue 1, pp. 6-27.

Wright, B.E. and Pandey, S.K. 2008. Public service motivation and the assumption of personorganisation fit: Testing the mediating effect of value congruence. Administration and Society, Vol. 40 Issue 5, pp. 502-521.

Yun, Y.J. and Lee, K.J. 2017. Social skills as a moderator between R\&D personnel's knowledge sharing and job performance. Journal of Managerial Psychology, Vol. 32 Issue 5, pp. 387-400. 